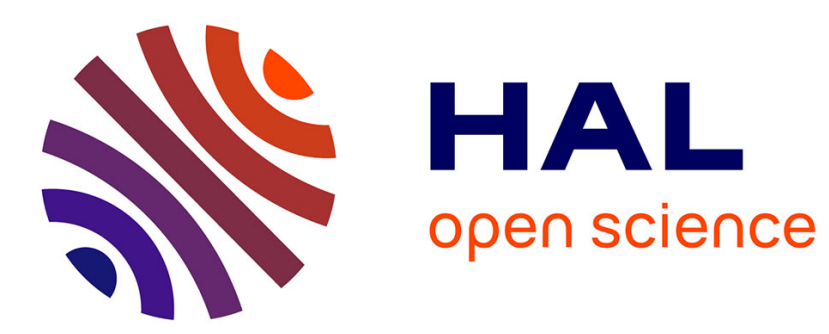

\title{
Theme C: Medical information systems and databases - results and future work
}

Nathalie Souf, Christine Verdier, André Flory, Marie-Christine Jaulent

\section{To cite this version:}

Nathalie Souf, Christine Verdier, André Flory, Marie-Christine Jaulent. Theme C: Medical information systems and databases - results and future work. Innovation and Research in BioMedical engineering, 2013, vol. 34 ( $\left.\mathrm{n}^{\circ} 1\right)$, pp. 9-10. 10.1016/j.irbm.2012.12.010 . hal-01131142

\section{HAL Id: hal-01131142 \\ https://hal.science/hal-01131142}

Submitted on 13 Mar 2015

HAL is a multi-disciplinary open access archive for the deposit and dissemination of scientific research documents, whether they are published or not. The documents may come from teaching and research institutions in France or abroad, or from public or private research centers.
L'archive ouverte pluridisciplinaire HAL, est destinée au dépôt et à la diffusion de documents scientifiques de niveau recherche, publiés ou non, émanant des établissements d'enseignement et de recherche français ou étrangers, des laboratoires publics ou privés. 


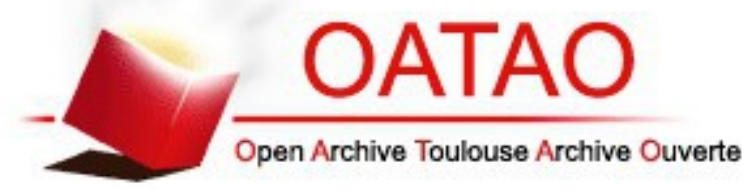

\section{Open Archive TOULOUSE Archive Ouverte (OATAO)}

OATAO is an open access repository that collects the work of Toulouse researchers and makes it freely available over the web where possible.

This is an author-deposited version published in : http://oatao.univ-toulouse.fr/ Eprints ID : 12393

To link to this article : DOI :10.1016/j.irbm.2012.12.010

URL : http://dx.doi.org/10.1016/j.irbm.2012.12.010

To cite this version : Souf, Nathalie and Verdier, Christine and Flory, André and Jaulent, Marie-Christine Theme C: Medical information systems and databases - results and future work. (2013) IRBM, vol. 34 (n 1). pp. 9-10. ISSN 1959-0318

Any correspondance concerning this service should be sent to the repository administrator: staff-oatao@,listes-diff.inp-toulouse.fr 


\title{
Theme C: Medical information systems and databases - results and future work
}

\author{
N. Bricon-Souf ${ }^{\mathrm{a}, *}$, C. Verdier ${ }^{\mathrm{b}}$, A. Flory ${ }^{\mathrm{c}}$, M.C. Jaulent $^{\mathrm{d}}$ \\ ${ }^{a}$ Institut de Recherche en Informatique de Toulouse, UMR 5505, UPS, 31062 Toulouse cedex 9, France \\ b Laboratoire d'Informatique de Grenoble, 38400 St Martin d'Hères, France \\ ${ }^{\mathrm{c}}$ LIRIS UMR 5205, Insa Lyon, 69621 Villeurbanne cedex, France \\ d INSERM UMRS 872, équipe 20, 75006 Paris, France
}

\begin{abstract}
This paper presents the activities of the theme C "medical information systems and databases" in the GDR Stic Santé. Six one-day workshops have been organized during the period 2011-2012. They were devoted to 1) sharing anatomical and physiological object models for simulation of clinical medical images, 2) advantages and limitations of datawarehouse for biological data, 3) medical information engineering, 4) systems for sharing medical images for research, 5) knowledge engineering for semantic interoperability in e-health applications, and 6) using context in health. In the future, our activities will continue with a specific interest on information systems for translational medicine and the role of electronic healthcare reports in decision-making. Workshops with other research groups will be organized in particular with the e-health research group.
\end{abstract}

\section{Aims}

The research theme "medical information systems and databases" is dedicated to the development of information systems in the areas of health research. It aims at developing active collaborations between researchers in this area, including other partners, such as health actors and developing relationships with industrial partners.

Medical information is complex and multimodal, it integrates free texts as well as codes or images for instance, it corresponds to data acquired during a patient examination (biology, imaging, etc.), but also to knowledge (case databases, statistical models, or symbolic models), it occurs in multiple resources such as medical records including patient records, DMP (a French national personnel patient record), or in large databases such as medical registries and experimental databases, in literature, in terminologies and ontologies, or in good practice guidelines.

Information processing plays an important role in healthcare activities and in biomedical research. The coverage of the field is large, extending from computerized prescription and comput-

\footnotetext{
* Corresponding author.

E-mail address: nathalie.souf@iut-tlse3.fr (N. Bricon-Souf).
}

erized patient records to systems accelerating the exploitation of new results from research and reducing errors. The role of medical information systems is therefore not only to provide information storage and access but also to process information.

Information systems combine multiple, distributed and heterogeneous components and their development raises major issues concerning, among other things:

- integration of heterogeneous data and semantic interoperability, international norms such as HL7 or CEN TC 251, national interoperability framework for health information systems have to be integrated in this research area;

- quality of medical data storage and accessibility, data processing, conceptuals datamodels, semantic datawarehouses, ontologies and medical terminologies are proposed [1];

- knowledge extraction, information retrieval, use of context are some of the open challenges [2,3]. Quality indicators as well as assessment of medical practices could emerge from this stage;

- development of decision support systems [4], whose knowledge could emerge from data mining for instance. The computerisation of guidelines is very challenging; 
- and finally the development of translational research that aims to develop innovative solutions to integrate biomedical data from heterogeneous sources, but inherently different and thus facilitate direct links between basic research and patient care.

The activities of the research group "medical information systems and database" aims to boost exchanges between the different communities involved in the design, production, distribution and use of medical information systems and could facilitate the response to different research calls such as the French ANR ones.

\section{Results for the period 2011-2012}

During the last period, six scientific workshops were organized: four of them were completely promoted by the theme, two of them were supported by the theme and linked to other manifestations.

25/01/2011: the first scientific meeting day was devoted to sharing anatomical and physiological object models for simulation of clinical medical images. It was held in Paris, Maison de la Recherche and organized by I. Buvat, T. Glatard and D. Friboulet. The purpose of the day was to provide some answers to share simulation models for medical image, gathering complementary points of view on the issue and including users of such simulators pictures, designers of such simulators and specialists in each modality, specialists in knowledge representation and in the representation of physiological knowledge or physical tissues and organs studied.

16/03/2011: the second meeting advantages and limitations of datawarehouse for biological data was proposed to bring together researchers and engineers in the fields of biology and computer (both producers and users of data) to examine the issues of the preservation and reuse of experimental data. It was held in Paris, Centre de Recherche des Cordeliers (CRC) and organized by G. Barlovatz-Meinon and M.C. Jaulent.

9-10/06/2011: the third one was involved in supporting the symposium on medical information engineering. It was held in Toulouse, IRIT-UPS and organized by L. Tamine, S. Darmoni and L. Soualmia. It discusses the issues related to modeling, structuring, extraction, search, for all types of information: structured form of data, or semi- or unstructured form of text, picture, sound.

19/12/2011: the fourth scientific meeting day was about systems for sharing medical images for research. It was held in Villejuif, Institut Gustave-Roussy and organized by B. Gibaud and E. Micard. It aims to review the availability and maturity of the proposed solutions. The issues to be discussed include: the functionalities of such systems, analyses of the specificities compared to the PACS and study of the interoperability with hospital PACS-Semantics shared data.
26/06/2012: the fifth day knowledge engineering for semantic interoperability in e-health applications was proposed during the Ingénierie des connaissances - knowledge engineering (IC) annual meeting held in Paris, CRC. It was organized by M.C. Jaulent and L. Soualmia. The objective of the workshop was to bring together knowledge engineering and resources for semantic interoperability in health (sharing and reuse), and present it in various ways: their construction, evaluation, languages and standards to represent them.

27/09/2012: the sixth day was on using context in health. It was held in Paris, CRC and organized by N. Souf and M.C. Jaulent. It aims to compare the experiences of researchers, industrial or healthcare professionals faced with a problem of taking into account contextual aspects in the use of health information systems. Some issues are anticipated: the elicitation of interesting contexts [5], the integration of context information in mobile usage, the use of contextual information for research, the use of context for decision support systems.

\section{Future plans (work in progress)}

In the future, our activities will continue on semantic interoperability for medical information systems. We will develop our researches with a specific interest on information systems for translational medicine, the role of electronic healthcare reports in decision-making and the use of context in medical applications. Workshops with other research groups will be organized in particular with the e-health research group.

\section{Disclosure of interest}

The authors declare that they have no conflicts of interest concerning this article.

\section{References}

[1] Ba M, Diallo G. ServOMap and ServOMap-lt results for OAEI 2012. In: The 7th International Workshop on Ontology Matching (OM 2012), collocated with the 11th International Semantic Web Conference (ISWC'2012). 2012.

[2] Darmoni SJ, Soualmia LF, Letord C, Jaulent MC, Griffon N, Thirion $\mathrm{B}$, et al. Improving information retrieval using medical subject headings concepts: a test case on rare and chronic diseases. J Med Libr Assoc 2012;100(3):176-83.

[3] Dinh D, Tamine L, Boubekeur F. Factors affecting the effectiveness of biomedical document indexing and retrieval based on terminologies. Artif Intell Med 2012;12:00114-5.

[4] Douali N, De Roo J, Jaulent MC. Clinical diagnosis support system based on case based fuzzy cognitive maps and semantic web. Stud Health Technol Inform 2012;180:295-9.

[5] Souf N, Conchon E. A step forward the elicitation of context: application in healthcare (short paper). In: ECAI Workshop on Acquisition, Representation and Reasoning with Contextualized Knowledge (ARCOE 2012). 2012. 